\title{
$\mathrm{H}$
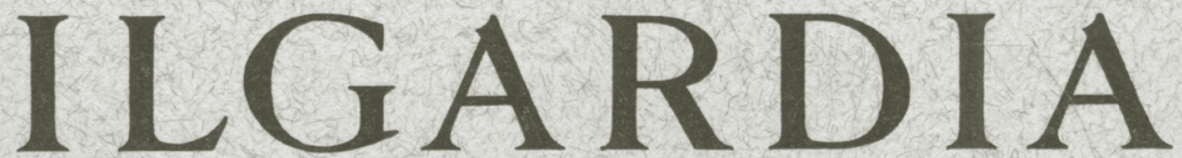

A Journal of Agricultural Science Published by the California Agricultural Experiment Station

\section{RESPONSE OF TOKAY GRAPES TO SPRAY APPLICATIONS OF 2,4-D}

R. J. WEAVER, O. A. LEONARD, and S. B. MCCUNE 
Tokay vines were sprayed, at different stages of development, with 2,4-D at 2 and $8 \mathrm{ppm}$, in 1958, 1959, and 1960. The effects from 2,4-D varied from year to year, with much injury in 1958 and 1959, and little or none in 1960 . There was little or no cumulative injury from low concentrations from one year to the next.

Most malformed foliage occurred from sprays applied when shoots were about 1 foot long and from sprays applied at the bloom or shatter stage. These sprayings were also most injurious to fruit.

Only extremely low concentrations of 2,4-D were found in fruit of sprayed vines, and only in berries sprayed in 1960 either at the shatter stage or at the final spraying. 


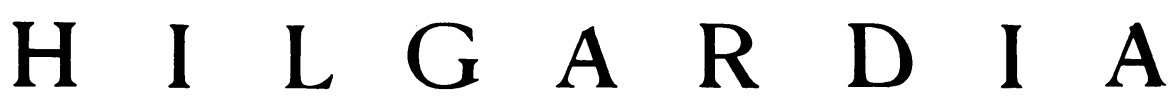

A Journal of Agricultural Science Published by

the California Agricultural Experiment Station

\begin{tabular}{lll} 
VoL. 31 & NovemBer, 1961 & No. 12 \\
\hline
\end{tabular}

\section{RESPONSE OF TOKAY GRAPES TO SPRAY APPLICATIONS OF 2,4-D}

\section{R. J. WEAVER, ${ }^{2}$ O. A. LEONARD, ${ }^{3}$ and S. B. MCCUNE ${ }^{4}$}

\section{INTRODUCTION}

GRAPES are gencrally very sensitive to 2,4-D (2,4-dichlorophenoxyacetic acid) (Weaver and Williams, 1951; Clore and Bruns, 1953 ; Weaver, Winkler, and McCune, 1958). Even minute applications can result in formative effects on the newly developing leaves, such as abnormal venation, cupping, stunting, and the like (Weaver and McCune, 1959a). Severe injury reduces leaf area and is presumed to be injurious to the vine. Whether mild symptoms can be associated with reduction in crop weight, fruit quality, and pruning weights has not been determined. The experiments described in this paper were performed in 1958,1959 , and 1960, on a block of Tokay grapes, to determine the injurious effects, if any, of small concentrations of 2,4-D applied at various developmental stages. The Tokay was selected because this variety has been shown to be very sensitive to 2,4-D, and has frequently been injured by spray drift of the chemical, especially in the Lodi, California, region (Weaver, Winkler, and McCune, 1958).

\section{MATERIALS AND METHODS}

The experiments were conducted in a block of seven 22-vine rows of Tokay grapes in an irrigated vinevard at the University of California, Davis. These 10-year-old vines were cordon-trained and spur-pruned (Winkler, 1931) and, other than the 2,4-D treatments, received normal routine vineyard care. The end vines were not used.

In 1958, vines were sprayed at each of five developmental stages with the ethanolamine salt of $2,4-\mathrm{D}^{6}$ at concentrations of 2 and $8 \mathrm{ppm}$, with untreated controls. No wetting agent was used as it was desired to keep droplets large in order to minimize drift. Spraying was done with $21 / 2$-gallon hand sprayers.

${ }^{1}$ Submitted for publication May 29, 1961.

" Professor of Viticulture and Viticulturist in the Experiment Station, Davis.

${ }^{3}$ Lecturer in Botany and Botanist in the Experiment Station, Davis.

${ }^{4}$ Senior Laboratory Technician in the Department of Viticulture and Enology, Daris.

"See "Literature Cited" for citations referred to in the text by author and date.

${ }^{\circ}$ Supplied by the Dow Chemical Company. 
At all sprayings, large cardboards were held around the vines to eliminate or minimize drift. There were three vines per treatment, and each three-vine plot was replicated three times in a randomized block design. In 1959 and 1960 , similar sprayings were made on the same vines. However, test vines of the fourth spraying were eliminated from the experiment because a concentration of 2,4-D higher than intended was accidentally applied to them in 1959.

Crop weights were obtained at harvest, and a 30-pound sample was used for fruit analysis. The looseness percentage-an estimate of total volume of a cluster not occupied by berries-was determined each year on the basis that controls had zero per cent unoccupied space (Weaver and McCune, $1959 b)$. A Balling hydrometer was used to determine percentage of total soluble solids in the juice. Total acidity was determined by diluting $10 \mathrm{ml}$ of juice to $50 \mathrm{ml}$ with distilled water, and titrating with $0.113 \mathrm{~N} / \mathrm{NaOH}$, using phenolphthalein as an indicator. Results are expressed as gm of tartaric acid per $100 \mathrm{ml}$ of juice. Cluster weights were measured in 1958, and berry weights in 1960 . Average weight of berries was determined by weighing 100 or 200 in duplicate. Weight of pruning brush was obtained in the dormant season following growth in 1958 and 1960.

For residue analysis, berries were macerated in a Waring blender, with 95 per cent alcohol. The macerated mixture was stored for about one month to remove the 2,4-D from the berry tissues, after which the amount of 2,4-D was determined by a cotton bioassay test previously described (Leonard, Weaver, and Kay, in press).

\section{EXPERIMENTATION AND RESULTS}

\section{Sprayings}

The stages of development of vines at time of spraying in 1958, 1959, and 1960 , are shown in table 1 . The shoots of all vines sprayed in the dormant season grew normally; no formative effects developed.

On May 9, control shoots ranged from 25 to 30 inches in length. Leaves on shoots sprayed with 2,4-D at $2 \mathrm{ppm}$ on April 28 were slightly injured, and those sprayed at $8 \mathrm{ppm}$ were severely injured (fig. 1). The degree of leaf injury ranged from slight formative effects to ribbon-like leaves that failed to expand (fig. 2).

On May 2, 10 shoots were measured in each plot of the first and second treatments. The average lengths in the dormant spraying were: control, 22.2 inches; 2,4-D at $2 \mathrm{ppm}, 22.5$ inches; 2,4-D at $8 \mathrm{ppm}, 22.5$ inches. For the second treatment, in the same order, the figures were 22.2, 22.0, and 20.4 inches. A reduction in shoot growth was thus apparent as early as four days after an application of 8 ppm 2,4-D.

By June 12, shoots sprayed on April 28 with 2,4-D at 2 ppm showed considerable 2,4-D symptoms. No injury was evident on the three basal leaves which apparently were mature at the time of treatment. The fourth leaf usually showed slight symptoms, and leaves farther out on the shoot showed progressively more severe symptoms. The shoots had not yet outgrown the effects, because normal leaves were not developing. Laterals arising from the 
fourth node showed symptoms, but those from more apical nodes usually showed none, even though leaves on the main shoot often did. 2,4-D at $8 \mathrm{ppm}$, applied on April 28, had reduced the foliage surface by about 50 per cent; shoots bore only small, stunted leaves. Two thirds of the berries had failed to enlarge, and many calyptras had failed to fall off at flowering time.

On June 12 it was observed that vines sprayed on May 14 (early bloom stage) also were markedly affected. Although the clusters on shoots sprayed with 2,4-D at $2 \mathrm{ppm}$ appeared normal, the apical half of the shoots had many small, deformed leaves; leaf area appeared to be about 30 per cent less than

TABLE 1

STAGE OF DEVELOPMENT OF TOKAY VINES AT TIMES OF SPRAYING WITH 2,4-D IN 1958, 1959, AND 1960

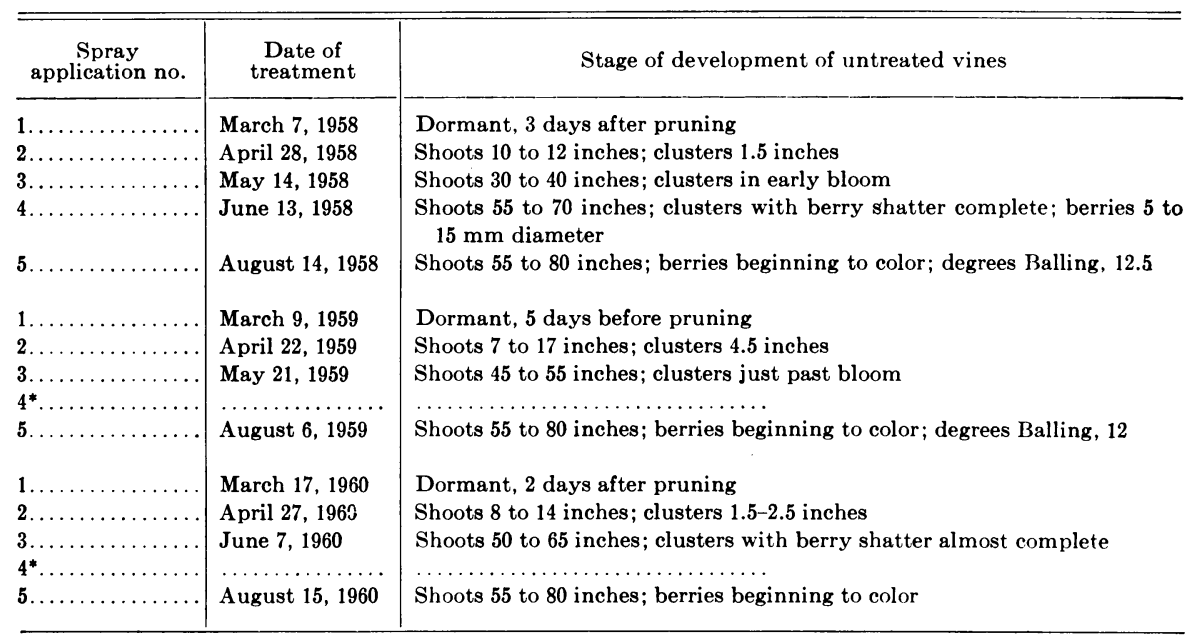

* Vines eliminated from experiment because of overdose of spray.

on the control vines. Fruit was also normal on vines sprayed at 8 ppm. However, the apices of three fourths of the total number of shoots were dead and dry. Shoots had apparently lengthened very little since time of treatment, and the amount of foliage was approximately 50 per cent that of the controls.

On August 14 it was noted that vines sprayed with 2,4-D at 2 ppm on June 13 (shatter stage) showed a reduction in foliage and many shot berries (small, seedless berries that failed to enlarge). At $8 \mathrm{ppm}$ the compound resulted in more shot berries than at $2 \mathrm{ppm}$.

Final observations on the foliage were made on October 7,1958 , when about 60 per cent of the total surface of control berries was colored. Some shoots sprayed on April 28 with 2,4-D at 2 or $8 \mathrm{ppm}$ had outgrown the effect of the compound, as indicated by the younger leaves, which were normal. On many of the shorter shoots, however, even the leaves at the apex showed 2,4-D symptoms. Many lateral shoots had normal leaves even though the leaf subtending the lateral shoot showed severe symptoms.

Vines sprayed on May 14 showed more 2,4-D symptoms when observed on October 7 than did those sprayed on April 28. Few foliage symptoms showed 


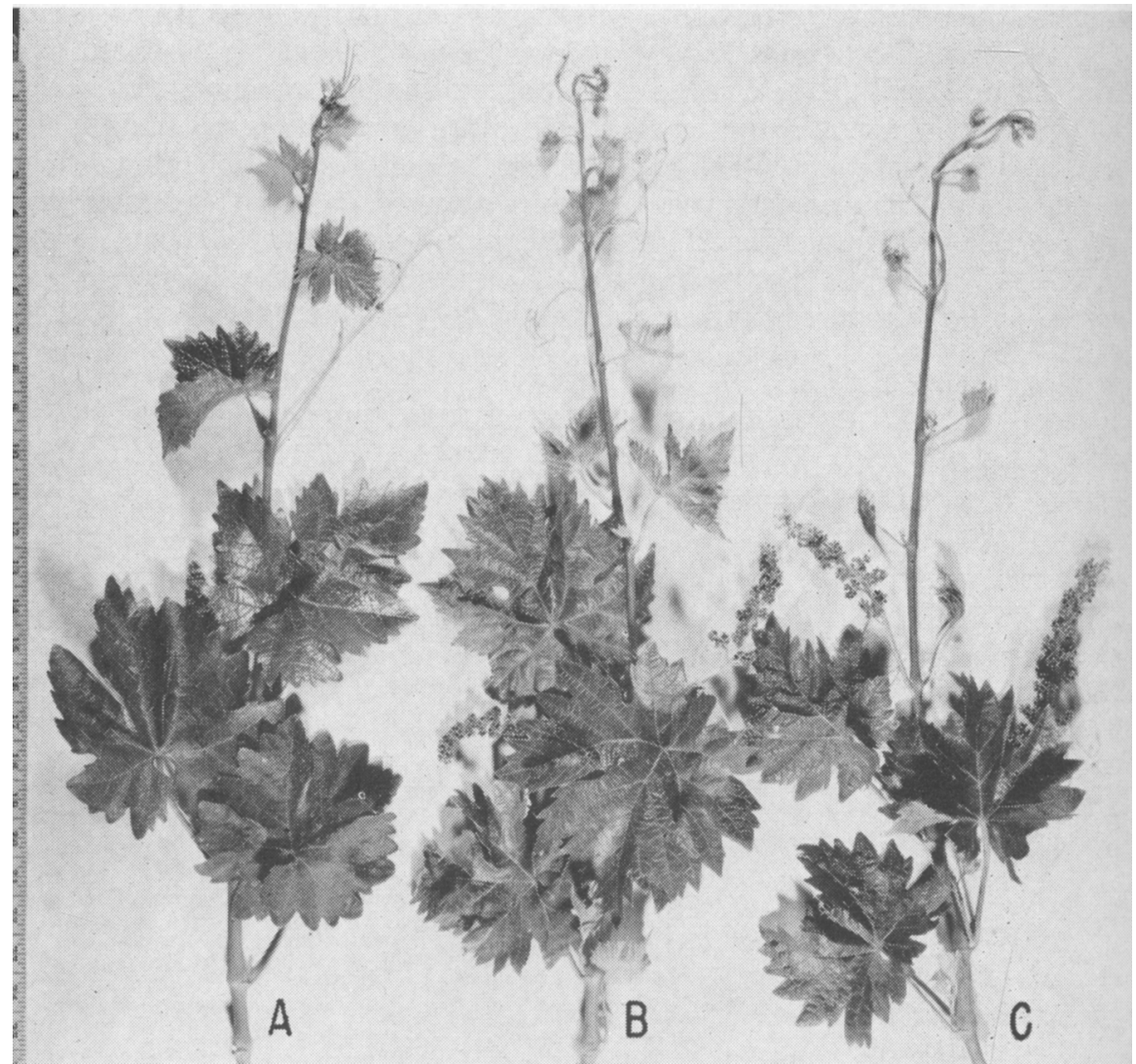

Fig. 1. Tokay shoots two weeks after being sprayed with 2,4-D at 2 (B) or 8 ppm (C) on April 28, 1958. (A) is unsprayed control. Note that newly dereloping leaves on shoot sprayed with 2,4 D at $2 \mathrm{ppm}$ (B) show some repression of growth, and that those sprayed at $8 \mathrm{ppm}$ (C) show severe stunting and crumpling, and shoots are bent. Older leaves and clusters show no apparent injury. (Photographed May 12, 1958.)

on rines sprayed on June 13, and very few symptoms could be found on vines sprayed on August 14.

Fruit was harvested on October 10, 1958, and tested for crop weights, weight per cluster, weight per berry, looseness percentage, degrees Balling, and percentage of acid (table 2 ).

Crop weights were depressed by the 2,4-D as a result of stage 2 and 3 applications. The compound applied at $8 \mathrm{ppm}$ on April 28 caused most damage. At $8 \mathrm{ppm}$, weight per cluster was reduced on these two dates. The looseness percentage, which reflects increasing numbers of shot berries, greatly increased as a result of stage 2 and 3 applications. A slight increase also resulted from the stage 4 application. The earlier the spray date, the greater was the injury, except that none was caused by the dormant-season spray applied on March 7 . Balling readings were highest on vines that received stage 2 and 3 applications of $8 \mathrm{ppm}$, probably as a result of the lower level 


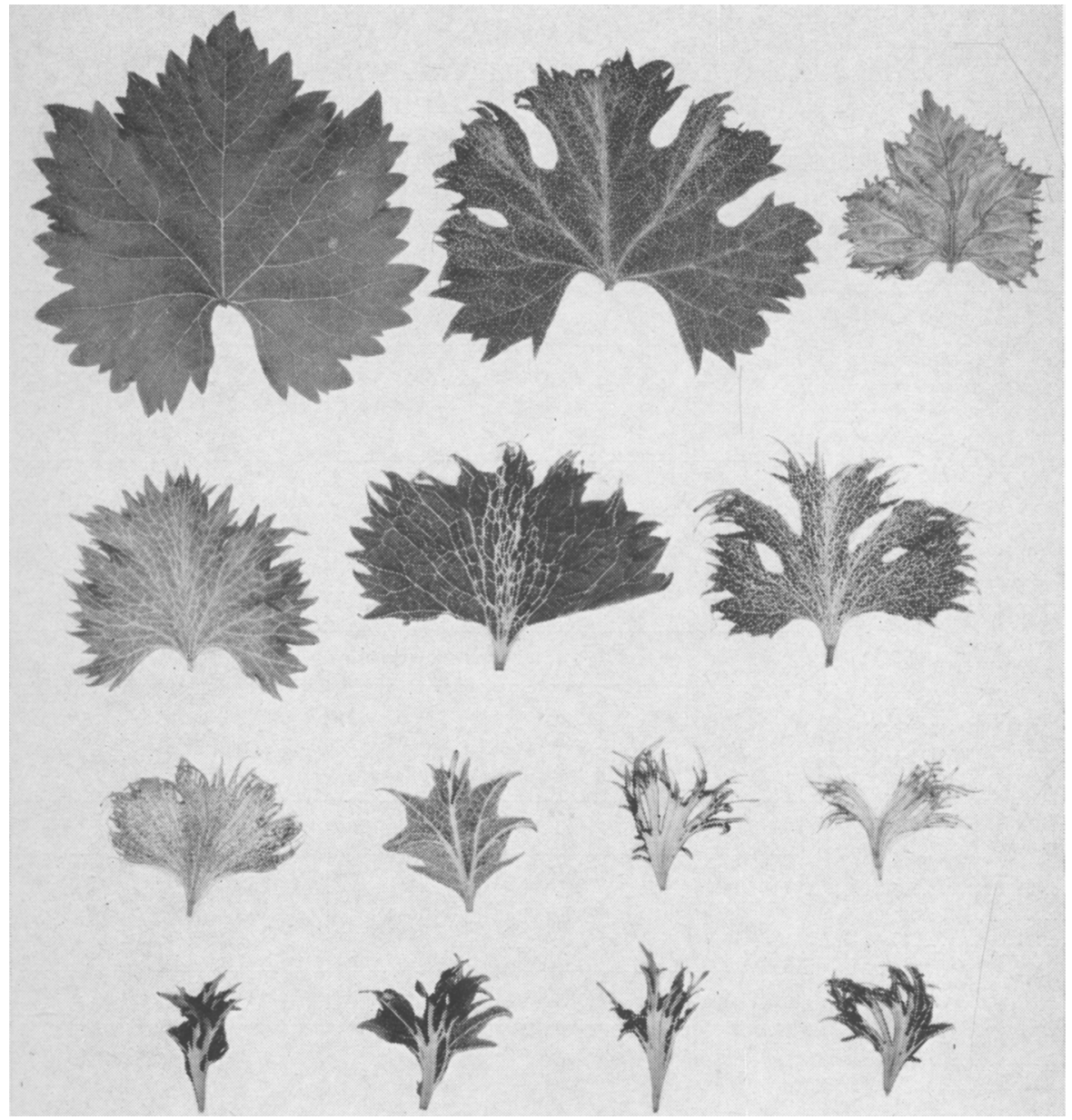

Fig. 2. Tokay leaves from shoots two weeks after being sprayed with 2,4-D at $8 \mathrm{ppm}$ on April 28, 1958. Control, top row, left. Note degree of injury ranges from leaves with slight formative effects to those that failed to expand, and appear strap-like. (Photographed May 12, 1958.)

of erop on these vines. Pruning brush weights obtained on Mareh 14, 1959, were erratic and showcd no definite trends (table 2).

\section{Sprayings}

Sprays were applied when vines were at four developmental stages (table 1). On June 3, when berry shatter was complete, no 2,4-D symptoms showed on vines sprayed in the dormant season, nor did any appear later in this treatment in 1959. The shoots sprayed at stage 2 with $2 \mathrm{ppm}$ showed many formative effects, and most leaves on vines sprayed with 2,4-D at 8 ppm showed symptoms, including straggly clusters. Vines sprayed at stage 3 also showed some 2,4-D symptoms, although considerably fewer than did corresponding 
TABLE 2

DATA AT HARVEST (OCTOBER 10, 1958) FOR TOKAY GRAPES SPRAYED WITH 2,4-D AT VARIOUS TIMES IN 1958

(Figures are averages of three replicate plots.)

\begin{tabular}{|c|c|c|c|c|c|}
\hline \multirow{2}{*}{ Concentration of 2,4-D } & \multicolumn{5}{|c|}{ Spraying dates } \\
\hline & $3 / 7 / 58$ & $4 / 28 / 58$ & $5 / 14 / 58$ & $6 / 13 / 58$ & $8 / 14 / 58$ \\
\hline \multirow{3}{*}{$\begin{array}{l}0 \ldots \\
2 \ldots \\
8 \ldots\end{array}$} & \multicolumn{5}{|c|}{ Crop weight per vine $(\mathrm{lb})^{*}$} \\
\hline & $\begin{array}{l}69.2 \\
65.0 \\
67.9\end{array}$ & $\begin{array}{l}66.4 \\
57.9 \\
27.4\end{array}$ & $\begin{array}{l}67.3 \\
57.0 \\
39.4\end{array}$ & $\begin{array}{l}65.3 \\
65.0 \\
64.4\end{array}$ & $\begin{array}{l}65.7 \\
63.8 \\
70.9\end{array}$ \\
\hline & \multicolumn{5}{|c|}{ Cluster weight (gm) } \\
\hline \multirow[t]{2}{*}{ 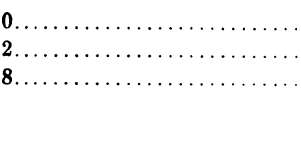 } & $\begin{array}{l}785 \\
665 \\
790\end{array}$ & $\begin{array}{l}778 \\
677 \\
446\end{array}$ & $\begin{array}{l}730 \\
757 \\
534\end{array}$ & $\begin{array}{l}687 \\
801 \\
698\end{array}$ & $\begin{array}{l}800 \\
812 \\
833\end{array}$ \\
\hline & & & ss percen & & \\
\hline \multirow[t]{2}{*}{ 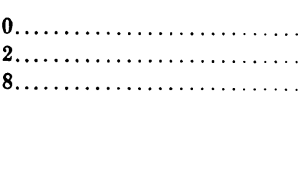 } & $\begin{array}{l}0 \\
0 \\
0\end{array}$ & $\begin{array}{r}0 \\
50 \\
70\end{array}$ & $\begin{array}{r}0 \\
20 \\
50\end{array}$ & $\begin{array}{l}0 \\
5 \\
5\end{array}$ & $\begin{array}{l}0 \\
0 \\
0\end{array}$ \\
\hline & \multicolumn{5}{|c|}{ Degrees Balling* } \\
\hline 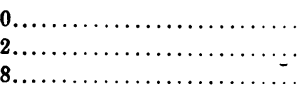 & $\begin{array}{l}16.0 \\
15.6 \\
15.7\end{array}$ & $\begin{array}{l}16.1 \\
17.3 \\
21.7\end{array}$ & $\begin{array}{l}16.2 \\
16.9 \\
19.2\end{array}$ & $\begin{array}{l}16.8 \\
15.9 \\
16.3\end{array}$ & $\begin{array}{l}16.6 \\
16.4 \\
15.9\end{array}$ \\
\hline $8, \ldots \ldots \ldots, \ldots, \ldots, \ldots, \cdots$, & \multicolumn{5}{|c|}{ Total acid, per cent tartaric* } \\
\hline 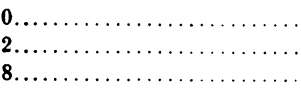 & $\begin{array}{l}0.57 \\
0.58 \\
0.57\end{array}$ & $\begin{array}{l}0.58 \\
0.58 \\
0.54\end{array}$ & $\begin{array}{l}0.49 \\
0.51 \\
0.50\end{array}$ & $\begin{array}{l}0.53 \\
0.55 \\
0.55\end{array}$ & $\begin{array}{l}0.59 \\
0.58 \\
0.55\end{array}$ \\
\hline $8, \ldots \ldots \ldots \ldots \ldots \ldots \ldots \ldots \ldots$ & \multicolumn{5}{|c|}{ Pruning brush weight per vine (lb)* } \\
\hline 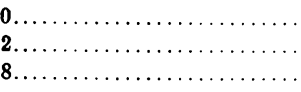 & $\begin{array}{l}2.93 \\
2.30 \\
2.60\end{array}$ & $\begin{array}{l}3.10 \\
2.43 \\
4.80\end{array}$ & $\begin{array}{l}3.00 \\
2.13 \\
2.13\end{array}$ & $\begin{array}{l}2.43 \\
2.77 \\
2.63\end{array}$ & $\begin{array}{l}3.13 \\
2.70 \\
2.77\end{array}$ \\
\hline
\end{tabular}

* d .os between concentrations at a given spraying date: crop weights, 4.4; degrees Balling, 3.3; percentage of acid, N.S.; and pruning weights, N.S.

d.os between spraying dates at a given concentration: crop weights, 5.2; degrees Balling, 1.7; percentage of acid, N.S.; and pruning weights, N.S.

vines sprayed at stage 2. By August 6 the 2,4-D symptoms caused by the stage 2 and 3 applications were less apparent because they were partially masked by the newly developing leaves.

Fruit was harvested on September 27, and crop yields were obtained (table 3). There was considerable rot in the fruit at time of harvest. Crop weights were reduced only by the stage 2 and 3 applications (table 3 ). The looseness percentages were increased most by the second sprayings (April 22) 
TABLE 3

DATA AT HARVEST (SEPTEMBER 27, 1959) FOR TOKAY GRAPES SPRAYED WITH 2,4-D AT VARIOUS TIMES IN 1958 AND 1959

(Figures are averages of three replicate plots.)

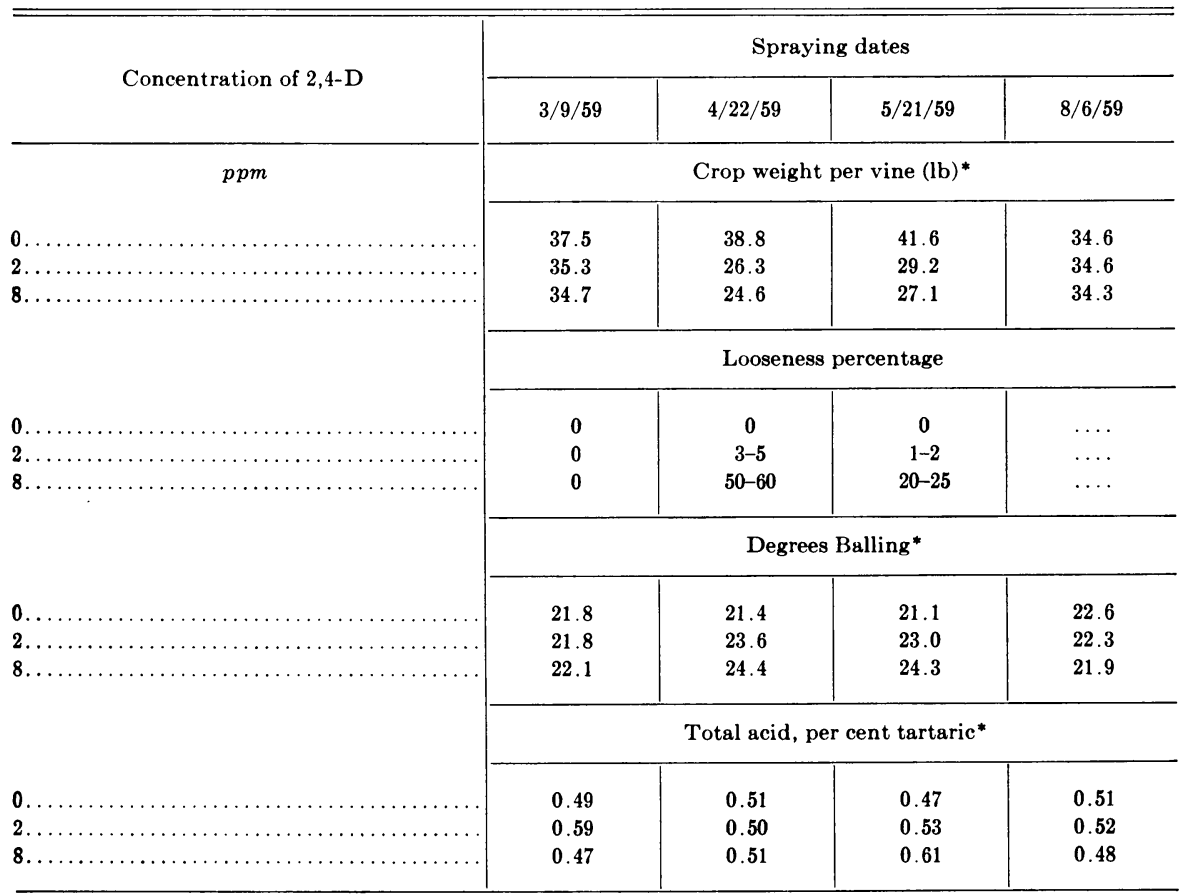

* d .05 between concentrations at a given spraying date: crop weights, 7.9; degrees Balling, 1.7; percentage of acid, 0.09 . acid, 0.05 .

but also to a considerable extent by the third. Balling readings were again higher in vines sprayed at the second and third treatments, and again this was probably the result of the lighter crops on those vines in the seasons of 1958 and 1959. The total acid of vines sprayed on April 22 was about the same as in the controls. It was higher in fruit sprayed with 2,4-D at $8 \mathrm{ppm}$ on May 21.

\section{Sprayings}

Sprays were applied at four developmental stages (table 1). The second spraying was applied on April 27, 1960, between 9:00 and 10:00 a.m. A light rain began at 2:00 p.m., and rain fell intermittently through the following night. The total rainfall was about 0.94 inch.

On April 27 it was noted that 2,4-D symptoms had been produced on the leaves by the March 17 treatment, which was applied in the dormant season. A few symptoms resulted from the application at $2 \mathrm{ppm}$, and at $8 \mathrm{ppm}$ much stunting of shoot and leaf growth occurred (figure 3 ). By June 7 , vines sprayed with 2,4-D at $2 \mathrm{ppm}$ on April 27, 1960, showed some symptoms on 

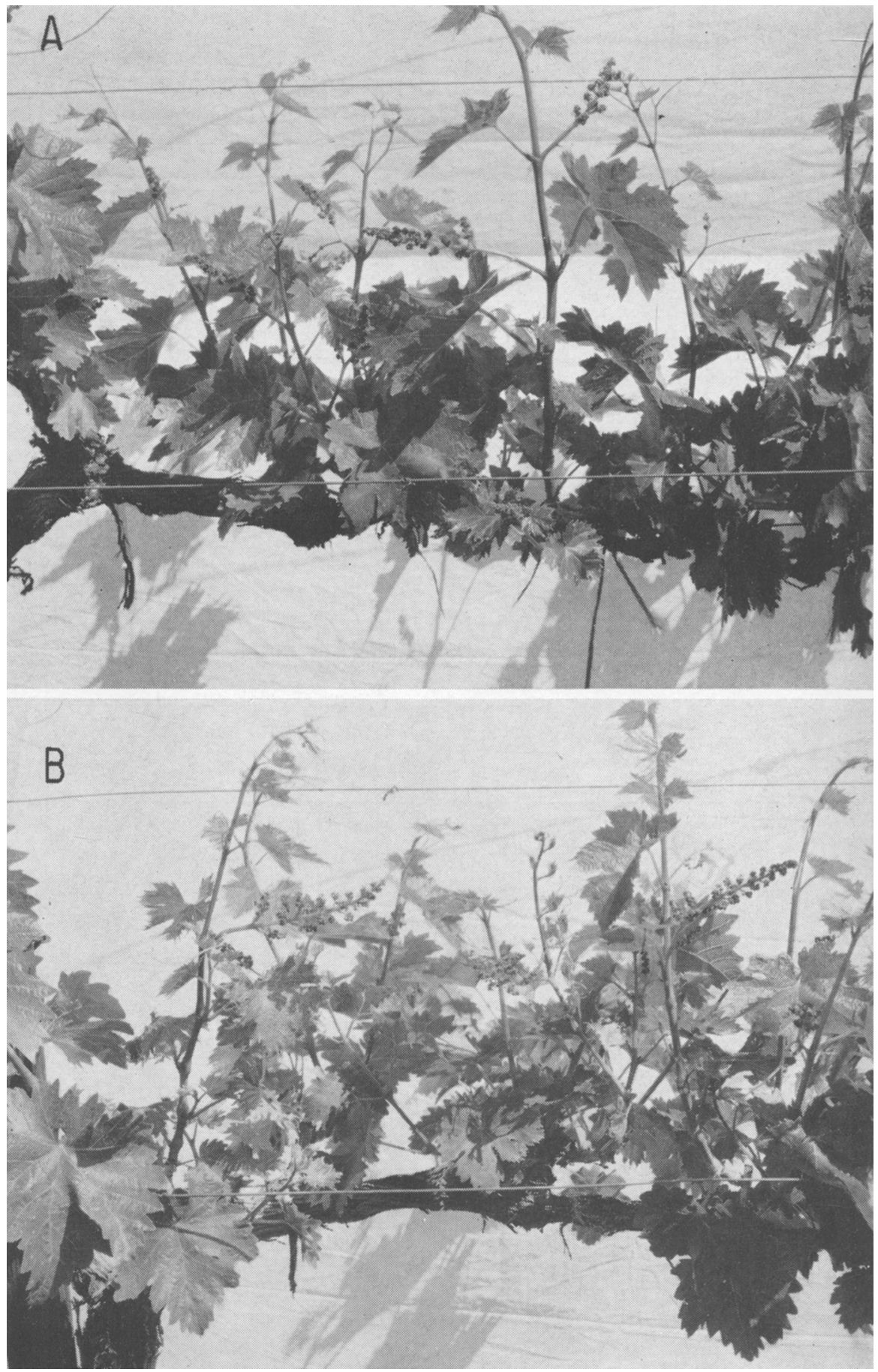


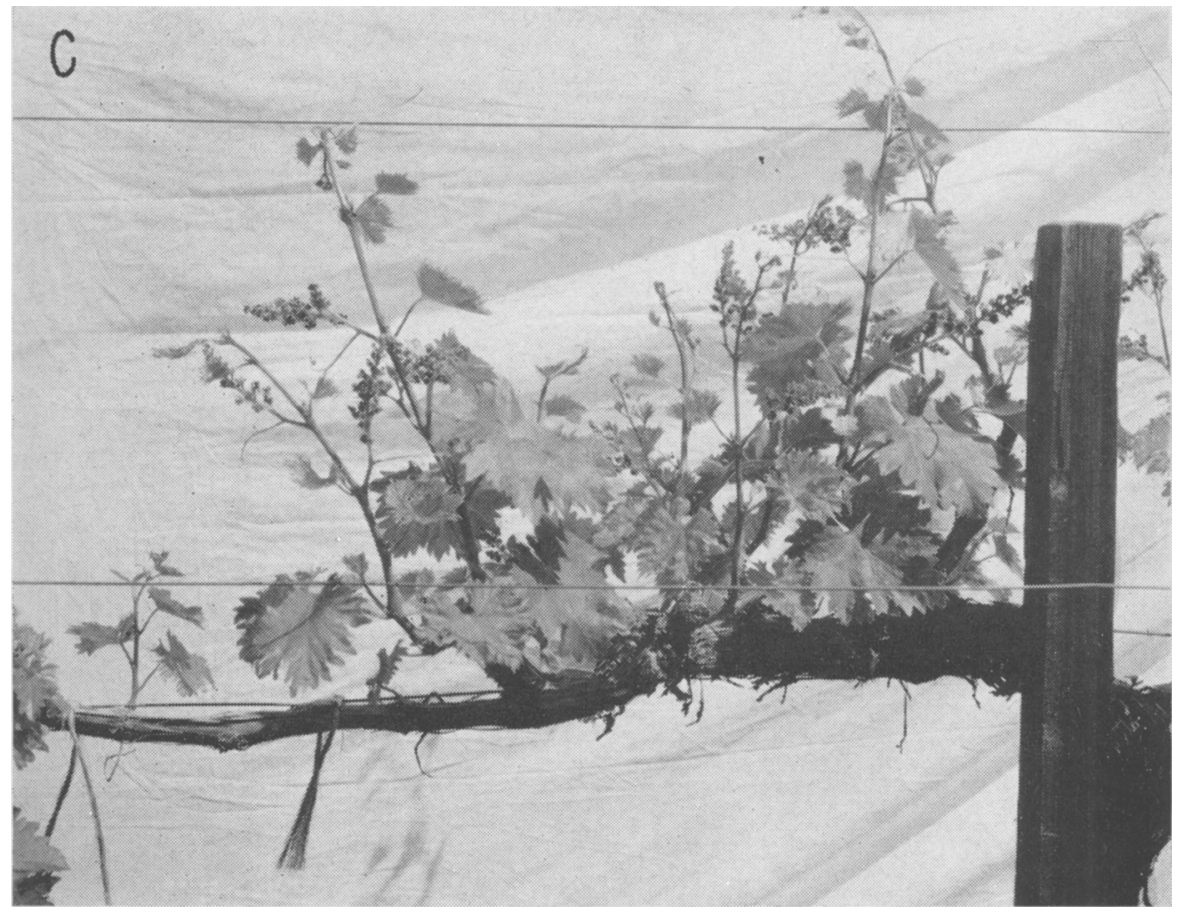

Fig. 3. (Opposite page and above): Tokay cordons 50 days after being sprayed in dormant season (March 17, 1960) with 2,4-D at 2 (B) or $8 \mathrm{ppm}(\mathrm{C})$. (A) is unsprayed cordon. Note that compound at $2 \mathrm{ppm}$ (B) has caused some 2,4-D symptoms, and that at $8 \mathrm{ppm}$ severe stunting has occurred. (Photographed May 6, 1960.)

leaves. Of those sprayed at $8 \mathrm{ppm}$, about one-half the total number of shoots showed symptoms.

By August 15, control fruit was beginning to color. Many shoots of the first three treatments showed symptoms, especially on apical parts. Foliage malformation was greater as a result of $2,4-\mathrm{D}$ at $8 \mathrm{ppm}$ than at $2 \mathrm{ppm}$. There were many shot berries in sprayed clusters.

Fruit was harvested and final obscrvations of foliage were made on September 23,1960 . Only a few leaf symptoms could be found on vines spraved with $2,4-\mathrm{D}$ at $2 \mathrm{ppm}$ at the first spraying, but on those sprayed at $8 \mathrm{ppm}$ some symptoms were still evident. Leaf deformation often occurred at the shoot apices; some was present even at the fifteenth node. Although some symptoms were apparent in vines of the second spraying, the over-all growth appeared normal. Symptoms were difficult to find on any vines of either the third or the final sprayings.

At harvest, about 35 per cent of the total surface of control fruit was colored. The crop weights of sprayed vines were less, but not significantly so (table 4). There were no definite trends in weight per berry. Some loosening of clusters occurred as a result of shot berry formation at the second and 


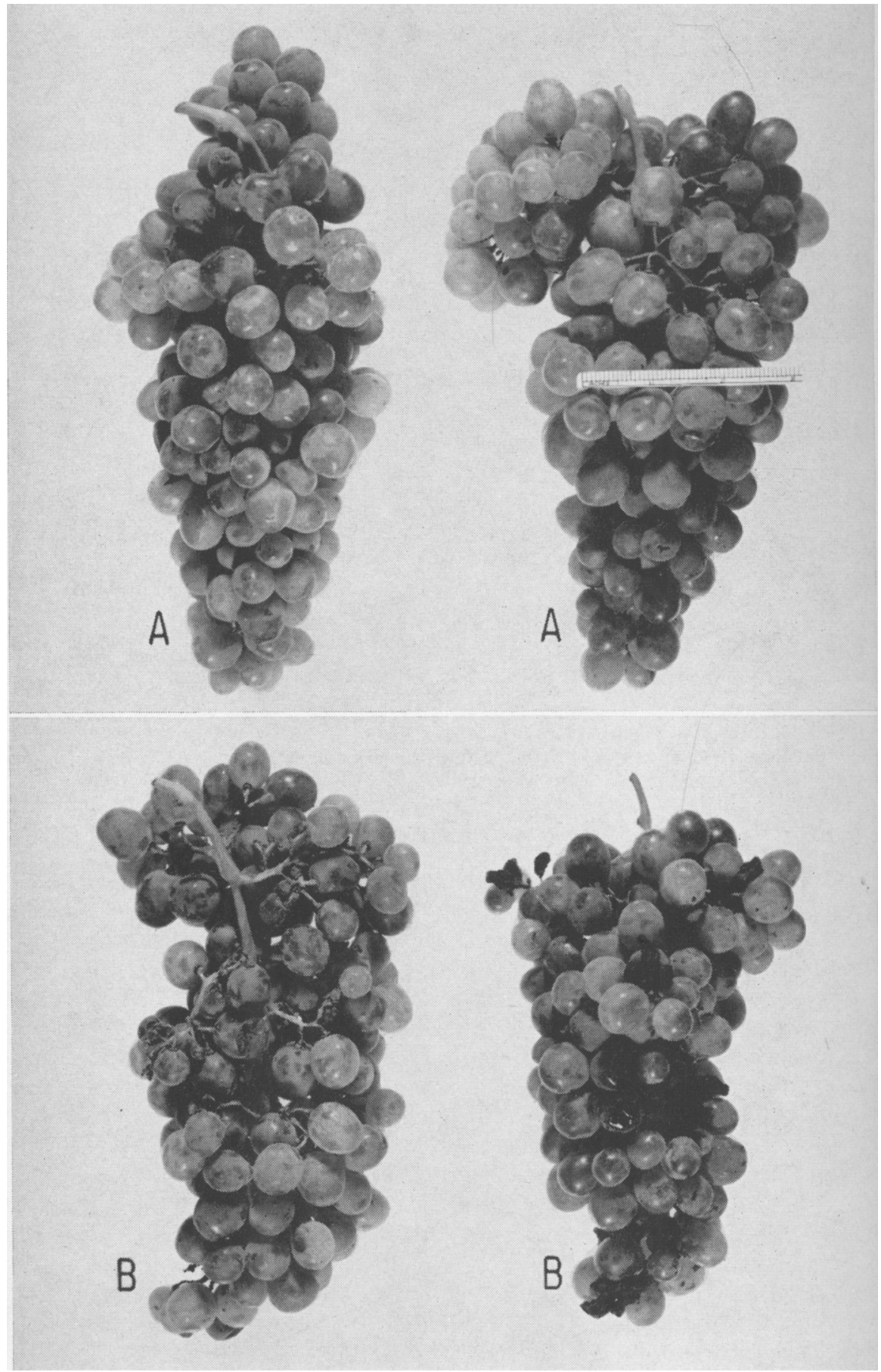

Fig. 4. Tokay clusters at harvest after being sprayed with 2,4-D at $8 \mathrm{ppm}$ (B) on June 7,1960 . (A) are unsprayed controls. Note presence of shot berries in sprayed fruit (B). (Photographed September 26, 1960.) 


\section{TABLE 4}

DATA AT HARVEST (SEPTEMBER 23, 1960) FOR TOKAY GRAPES SPRAYED WITH 2,4-D AT VARIOUS TIMES IN 1957, 1958, AND 1959

(Figures are averages of three replicate plots.)

\begin{tabular}{|c|c|c|c|c|}
\hline \multirow{2}{*}{ Concentration of 2,4-D } & \multicolumn{4}{|c|}{ Spraying dates } \\
\hline & $3 / 17 / 60$ & $4 / 27 / 60$ & $6 / 7 / 60$ & $8 / 15 / 60$ \\
\hline \multirow{3}{*}{ 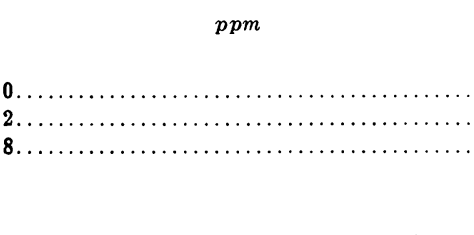 } & \multicolumn{4}{|c|}{ Crop weight per vine (lb)* } \\
\hline & $\begin{array}{l}52.9 \\
46.9 \\
40.9\end{array}$ & $\begin{array}{l}55.5 \\
46.8 \\
50.7\end{array}$ & $\begin{array}{l}53.2 \\
46.6 \\
47.6\end{array}$ & $\begin{array}{l}55.6 \\
46.7 \\
47.1\end{array}$ \\
\hline & \multicolumn{4}{|c|}{ Weight per berry (gm) } \\
\hline 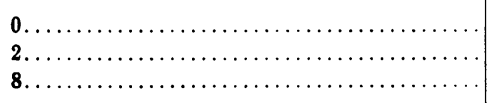 & $\begin{array}{l}3.71 \\
3.30 \\
3.82\end{array}$ & $\begin{array}{l}3.65 \\
3.68 \\
3.47\end{array}$ & $\begin{array}{l}3.89 \\
3.78 \\
3.75\end{array}$ & $\begin{array}{l}3.61 \\
3.74 \\
3.53\end{array}$ \\
\hline 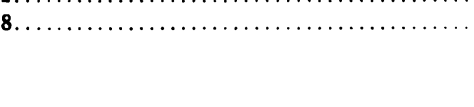 & \multicolumn{4}{|c|}{ Looseness percentage } \\
\hline \multirow[t]{2}{*}{ 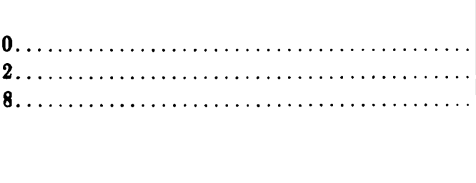 } & $\begin{array}{l}\mathbf{0} \\
\cdots \\
\cdots\end{array}$ & $\begin{array}{r}0 \\
10 \\
10\end{array}$ & $\begin{array}{c}0 \\
10-15 \\
10-15\end{array}$ & $\begin{array}{l}0 \\
0 \\
0\end{array}$ \\
\hline & \multicolumn{4}{|c|}{ Degrees Balling* } \\
\hline 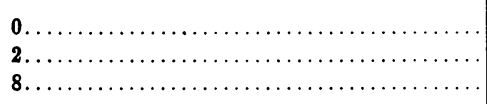 & $\begin{array}{l}17.6 \\
16.7 \\
19.2\end{array}$ & $\begin{array}{l}16.1 \\
18.1 \\
17.5\end{array}$ & $\begin{array}{l}16.4 \\
17.2 \\
16.5\end{array}$ & $\begin{array}{l}16.7 \\
16.7 \\
17.5\end{array}$ \\
\hline 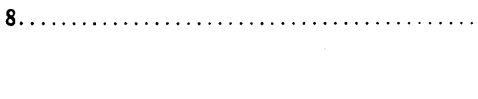 & \multicolumn{4}{|c|}{ Total acid, per cent tartaric* } \\
\hline $\begin{array}{l}0 \ldots \ldots \ldots \ldots \ldots \ldots \\
2 \ldots \ldots \ldots \ldots \ldots \ldots \ldots \\
8 \ldots \ldots \ldots \ldots \ldots \ldots\end{array}$ & $\begin{array}{l}0.59 \\
0.56 \\
0.53\end{array}$ & $\begin{array}{l}0.59 \\
0.55 \\
0.58\end{array}$ & $\begin{array}{l}0.56 \\
0.54 \\
0.52\end{array}$ & $\begin{array}{l}0.58 \\
0.57 \\
0.53\end{array}$ \\
\hline & \multicolumn{4}{|c|}{ Pruning brush weight per vine (lb)* } \\
\hline 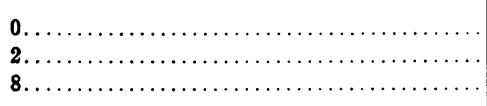 & $\begin{array}{l}4.28 \\
3.61 \\
4.22\end{array}$ & $\begin{array}{l}4.22 \\
3.50 \\
3.78\end{array}$ & $\begin{array}{l}3.89 \\
3.67 \\
4.33\end{array}$ & $\begin{array}{l}4.50 \\
3.81 \\
3.78\end{array}$ \\
\hline
\end{tabular}

* $\mathrm{d} .05$ between concentrations at a given spraying date and between spraying dates at a given concentration is N.S. in all cases.

third sprayings (figure 4). Degrees Balling and percentage of acid showed no definite trends.

\section{Residues of 2,4-D in the Fruit}

On September 6, 1960, about $420 \mathrm{gm}$ of berries were collected from each treatment at each spraying date. At that time the Balling reading was $15.8^{\circ}$ and percentage of acid 0.93 for the controls. The first alcoholic extraction removed 95 per cent or more of the $2,4-\mathrm{D}$; a detectable amount of $2,4-\mathrm{D}-1$ 
ppb (parts per billion) - was obtained in only one instance by the second extraction, and none was detected in the third extraction.

The data (table 5) show that there was no detectable 2,4-D in grapes of the first (dormant) spraying at either concentration, and only a trace in vines of the second spraying that were treated with compound at $8 \mathrm{ppm}$. In fruit sprayed with 2,4-D at $8 \mathrm{ppm}$ on the third and fifth dates, only the low amount of $30 \mathrm{ppb}$ was found in the berries.

TABLE 5

RESIDUAL CONCENTRATION* OF 2,4-D IN FRUIT OF TOKAY GRAPES FOLLOWING THREE ANNUAL APPLICATIONS

(Fruit harvested September 6, 1960.)

\begin{tabular}{|c|c|c|c|}
\hline Spray treatment no. & $\begin{array}{l}\text { Date sprayed } \\
\text { in } 1960\end{array}$ & $\begin{array}{l}\text { Concentra- } \\
\text { tion of } \\
2,4-D\end{array}$ & $\begin{array}{l}\text { Average } \\
2,4-D \\
\text { in fruit }\end{array}$ \\
\hline & & $p p m$ & $p p m \times 10^{-3}$ \\
\hline \multirow[t]{3}{*}{1.} & $3 / 17$ & 0 & 0 \\
\hline & & 2 & 0 \\
\hline & & 8 & 0 \\
\hline \multirow[t]{3}{*}{2.} & $4 / 27$ & 0 & 0 \\
\hline & & 2 & 0 \\
\hline & & 8 & Tr. \\
\hline \multirow[t]{3}{*}{3.} & $6 / 7$ & 0 & 0 \\
\hline & & 2 & 2 \\
\hline & & 8 & 30 \\
\hline \multirow[t]{3}{*}{$5 \ldots$} & $8 / 15$ & 0 & 0 \\
\hline & & 2 & 3 \\
\hline & & 8 & 30 \\
\hline
\end{tabular}

* $0.05 \mu \mathrm{g} 2,4-\mathrm{D}$ was considered the minimum quantity that would produce strapshaped or cupped leaves of cotton seedlings.

\section{DISCUSSION}

The formative effects of 2,4-D on leaves of treated shoots probably vary according to the stage of leaf development at time of treatment. The younger the leaves at time of treatment, the more intense the formative effects; mature leaves showed no effects. The effect of stage of development of bean leaves at time of treatment on their response to 2,4-D has been shown (Eames, 1951).

On many shoots the effect of early sprays of 2,4-D persisted in the vines and was expressed on leaves developing late in the season. This suggests that 2,4-D can be moved in the vine for three to four months, but the total quantity moved after such periods must be extremely small. Leonard and Weaver (in press) found only barely detectable traces of radioactivity from carbon14-labeled 2,4-D in malformed young leaves three and one-half months after treatment; however, appreciable quantities were still present in the fruit. It is clear that 2,4-D is only very slowly inactivated within the grape shoot. Long persistence of 2,4-D in the cotton plant has also been reported by McIlrath and Ergle (1953). They found that leaf abnormalities occur on 
many more leaves than were present in the bud at the time of treatment. The persistence of 2,4-D in the grape and cotton plants is much longer than it is in many other plants, such as the common bean.

Only a few formative effects resulted from the final sprayings. This may be explained by the fact that shoot growth was quite limited after July 1 , so that there were only a few newly developing leaves. Furthermore, Leonard and Weaver (in press) have shown that translocation was primarily downward at that time, which would reduce the quantity of 2,4-D translocated to the shoot apices.

In 1958 and 1959, the vines were markedly affected by the second sprayings (when the shoots were 7 to 17 inches long), as indicated by crop weights, looseness percentage, and cluster weights. The third spraying (shoots 30 to 55 inches long, and from early bloom to just after blooming) was next in effectiveness. At the second spraying made when shoots were young, each shoot had proportionately more meristematic tissues than at the third spraying; these tissues are more responsive to growth regulators. It has also been shown that, usually, the younger the cluster, the greater is the damage from 2,4-D (Weaver, Leonard, and McCune, 1961).

The higher Balling reading of the fruit from the vines that were sprayed in 1958 and 1959 was probably a result of decreased crop (Winkler, 1931), although the 2,4-D may have had the effect of mobilizing sugars into the fruit.

The harvest data and pruning brush weight for 1960 showed little or no effect from three years of 2,4-D application. This would indicate that little or no cumulative injury results from low concentrations of 2,4-D from one year to the next. Some reduction in brush weights from the second and third applications in 1958 and 1959, with no reduction in 1960, indicates that climatic factors may influence the effect of such treatments on vine weights. Similar differences appeared to occur with respect to fruit weights.

In 1960 sprays, formative effects on the grape leaves were especially common from early applications made while the vines were dormant. Since these sprays were applied only two days after pruning, it is probable that 2,4-D entered the cuts and reached the buds. However, the treatments had no measurable effect on either the vines or the fruit (except, possibly, cluster looseness), but did produce malformed leaves. Why no symptoms occurred in 1958 on vines sprayed three days after pruning is not known. Perhaps the rate of bleeding was higher at that time, and the 2,4-D was washed off the stumps. Winter spray applications of 2,4-D (salts of emulsifiable acid) for control of weeds in vineyards probably ean be made safely on the basis of the results presented in this paper; however, care would certainly be necessary to keep the spray off the pruning wounds.

Our experiments with 2,4-D at 2 and $8 \mathrm{ppm}$ produced effects, in some cases, that were greater than intended-especially with those sprays that were applied just before and just after blooming. Additional studies must be made with lower levels of 2,4-D, in order to work out a more detailed description of vine symptoms which might be associated with degree of injury (reduction in crop yields). When this is done, it may be possible to appraise better the slight 2,4-D drift symptoms that are present on vines throughout the 
state (Weaver, Winkler, and McCune, 1958). Present results indicate that a precise evaluation of 2,4-D injury may be difficult, in view of the fact that no effects on fruit yield were evident on vines with malformed leaves, either in the June 13, 1958, treatment or in any 1960 treatments.

Residual 2,4-D was found in quantity only in fruit sprayed in 1960 either at the shatter stage or in the final spraying. It would be of interest to know how much 2,4-D remained on the surface of the fruit, and how much entered the fruit through the leaves. It might be surmised that much was deposited on the skin, since the fruit on vines sprayed at prebloom contained no 2,4-D. The exceedingly low concentrations found in the fruit ( $30 \mathrm{ppb})$, even on vines sprayed at $8 \mathrm{ppm}$ and showing severe symptoms, would appear to be safe from a residue standpoint. Even more minute amounts of 2,4-D have been detected by means of radioactive 2,4-D (Leonard and Weaver, in press).

The rainfall after the spraying on April 27, 1960, apparently did not reduce the formative effects of 2,4-D, as compared with those of later sprayings. However, total absorption of 2,4-D may have been reduced since fruit yields were not decreased in 1960, but were decreased in 1958 and 1959 by treatments applied at approximately the same stage of growth. Absorption of 2,4-D by the Tokay grape appears to occur slowly under field conditions (Leonard and Weaver, in press). Bean plants under field conditions required only 24 hours for much absorption of 2,4-D (Weaver, Minarik, and Boyd, 1946).

\section{SUMMARY}

1. Tokay vines were sprayed with $2,4-\mathrm{D}$ at 2 or $8 \mathrm{ppm}$, at five developmental stages in 1958, and four developmental stages in 1959 and 1960. Unsprayed controls served as checks. Most malformed foliage occurred from stage 2 (shoots about 1 foot long) and stage 3 (bloom or shatter). These sprayings also resulted in greatest injury to fruit as judged by crop weight, cluster weight, and looseness percentage. The second spraying usually caused more cluster damage than did the third.

2. The effects from 2,4-D varied from year to year. Much injury occurred in 1958 and 1959, but little or none in 1960. Rainfall after the spraying on April 27, 1960, may have reduced the effects of the 2,4-D, especially on yield.

3 . Little or no cumulative injury was indicated from low concentrations of 2,4-D from one year to the next.

4. 2,4-D was not bound in the vine soon after treatment. On many shoots the effect of early sprays of 2,4-D persisted and caused formative effects on leaves developing late in the season.

5. In 1958 and 1959, sprays of 2,4-D in the dormant season caused no leaf symptoms, but in 1960 many malformed leaves were present early in the season.

6. Only exceedingly low concentrations of 2,4-D (maximum, $30 \mathrm{ppb}$ ) were found in the fruit of sprayed vines. 2,4-D was found only in berries sprayed in 1960 either at the shatter stage or at the final spraying. 


\section{LITERATURE CITED}

Clore, W. J., and V. F. Bruns

1953. The sensitivity of the Concord grape to 2,4-D. Proc. Amer. Soc. Hort. Sci. 61: 125-34.

EAmes, ARthur J.

1951. Leaf ontogeny and treatments with 2,4-D. Amer Jour. Bot. 38(10):77i-80.

LeONARd, O. A., and R. J. Weaver

1961. Absorption and translocation of 2,4-D and amitrole in the shoots of Tokay grape. Hilgardia (in press).

Leonard, O. A., R. J. Weaver, and B. L. KaY

1961. Bioassay methods for determining 2,4-D in plant tissues. Weeds (in press).

McIlrath, W. J., and D. R. ERgLe

1953. Further evidence of the persistence of the 2,4-D stimulus in cotton. Plant Physiol. $28: 693-703$.

WeAver, R. J., and S. B. McCune

1959a. Test for activity of growth regulators on grapes. Bot. Gaz. $120(3): 166-70$.

$1959 \mathrm{~b}$. Effect of gibberellin on seeded Vitis vinifera, and its translocation with in the vine. Hilgardia $28(20): 624-45$.

WEAVER, R. J., and W. O. WILliams

1951. Response of certain varieties of grapes to plant growth regulators. Bot. Gaz. $113: 75-85$.

WeAver, R. J., A. J. Winkler, and S. B. MCCune

1958. Some effects of 2,4-dichlorophenoxyacetic acid and related compounds on the grapevine. Amer. Jour. Enol. $9(3): 126-38$.

Weaver, R. J., O. A. Leonard, and S. B. McCune

1961. Response of clusters of Vitis vinifera grapes to 2,4-D and related compounds. Hilgardia 31(5):113-25.

Weaver, R. J., C. E. Minarik, and F. T. Boyd

1946. Influence of rainfall on effectiveness of 2,4-D sprayed for herbicidal purposes. Bot. Gaz. 107:540-44.

WINKLER, A. J.

1931. Pruning and thinning experiments with grapes. California Agr. Exp. Sta. Bul. 519. 

The journal Hilgardia is published at irregular intervals, in volumes of about 600 pages. The number of issues per volume varies.

Subscriptions are not sold. The periodical is sent as published only to libraries, or to institutions in foreign countries having publications to offer in exchange.

You may obtain a single copy of any issue free, as long as the supply lasts; please request by volume and issue number from:
Agricultural Publications
207 University Hall
2200 University A venue
Berkeley 4, California

The limit to nonresidents of California is 10 separate issues on a single order. A list of the issues still available will be sent on request.

In our publications it is sometimes convenient to use trade names of products or equipment rather than scientific identifications. In so doing it is unavoidable in some cases that similar products which are on the market under other trade names may not be cited. No endorsement of named products is intended nor is criticism implied of similar products which are not mentioned. 
$4 x^{2} x$

$y^{2}+(x)+1$ $\frac{x}{4} x$

(1) दो

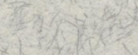

